DOI https://doi.org/10.32782/2305-9389/2020.22.11

УДК 94(477)«1920»

Сокирська Влада,

доктор історичних наук,

професор кафедри всесвітньої історії, міжнародних відносин та методики навчання історичних дисииплін Сумського державного педагогічного університету імені А.С. Макаренка

\title{
ВІДНОСИНИ МІЖ РСФРР ТА УСРР В 1919-1929 РР.: ВІД СУВЕРЕНІТЕТУ ДО УНІТАРИЗМУ
}

У статті доведено, щзо заходи, спрямовані на політичне опанування Радянською Росією України, йшли поза площиною правового оформлення державних стосунків Росії й України. У відносинах між РСФРР $і$ УСРР y 1920-х роках спостерігалося поєднання тактики інкорпорації засобами силової експансї̈ з підкресленим декларуванням незалежності Украӥни та прийняттям рішень, щчо перетворювали останню на автономію. Тому відносини між РСФРР і УСРР 1920-х роках - ие результат складної взаємодії історичних, політичних, економічних, культурних, соціально-психологічних, географічних чинників, випадковостей, зовнішніх впливів та внутрішніх процесів.

Міждержавні відносини РСФРР і УСРР трунтувалися на більшовищькій доктрині, спільності ідеологічних та політичних завдань, однаково організованого і на спільних засадах побудованого державного устрою та соиіально-економічного укладу. Незалежні радянські республіки формально мали статус самостійних держав у 1919 - початку 1920-х років, навіть були тісно пов'язані між собою. Роль иентру відігравала Російська Федерація, навколо якої гуртувалися решта радянських республік. Прагнення до об'єднання зумовлювалося економічними зв'язками між ними, щчо складалися протягом тривалого часу, однаковою політичною структурою, а також ідеологічними завданнями унітаризму, централізму, тоталітаризму правлячої більшовицької napmii.

3 утворенням Союзу Радянських Соціалістичних Республік змінилося правове становище республік із договірних на союзні. Відносин між республіками втратили характер міждержавних $i$ формувалися як міжреспубліканські. У результаті проведення адміністративно-територіальних перетворень 1920-х років иілеспрямована уніфікаторська політика керівництва СРСР у 1920-ті роки у питанні визначення російськоукраӥнського кордону призвела до того, щу великі за площею та населені переважно україниями землі залишилися поза межами політичних кордонів України.

Ключові слова: РСФРР, УСРР, СРСР, російсько-украӥнські відносини, федерація, унітаризм, російськоукраӥнський кордон.

\section{Sokyrska Vlada. Relations between the RSFSR and the Ukrainian SSR in 1919-1929: from sovereignty to unitarism}

In the course of the research it was established that measures aimed at political capture of Ukraine by Soviet Russia were beyond the legal framework of the state relations between Russia and Ukraine. In the 1920s the relations of the RSFSR with the Ukrainian SSR are characterized by the combination of incorporative tactics by means of power expansion with an emphasis on declarative Ukraine's independence and making decisions that transformed the latter into the autonomy. That is why the relations between the RSFSR and the Ukrainian SSR in the 1920s are the result of a complex interaction of historical, political, economic, cultural, social and psychological, geographic factors, accidents, external influences, and internal processes.

The interstate relations between the RSFSR and the Ukrainian SSR were based on the Bolshevik doctrine, common ideological and political tasks, the state system and the social and economic structure, organized within common basics. Independent soviet republics formally had the status of separate states in 1919-the beginning of the 1920s even being tightly connected. The Russian Federation played the role of the centre, around which the rest of the soviet republics united. The desire for unification was determined by economic ties between them, which had been developing for a long period of time, the same political structure as well as the ideological tasks of Unitarianism, centralism, and totalitarianism of the ruling Bolshevik Party.

The interstate relations between the RSFSR and the Ukrainian SSR were based on the Bolshevik doctrine, common ideological and political tasks, the state system and the social and economic structure, organized within common basics. As a result of administrative and territorial transformations in the 1920s Ukraine lost large territories in the East. The purposeful policy of the Union SSR in the 1920s led to the fact that the large lands, mostly inhabited by Ukrainians, remained beyond the boundaries of Ukraine's political borders.

Key words: RSFSR, Ukrainian SSR, Union SSR, Russian-Ukrainian relations, federation, Unitarianism, RussianUkrainian border. 
Нинішній стан російсько-українських відносин, як і в найближчій перспективі, є складником розпаду Російської імперії, що триває впродовж останніх ста років. Він має комплекс наслідків політичного, економічного, культурного та навіть ментального характеру. Сучасна Російська Федерація вважає себе правонаступницею колишніх імперій - Російської та Союзу РСР - і розглядає республіки, які набули самостійності в результаті розпаду СРСР, як сферу свого безпосереднього впливу. Незалежна Україна сприймається серед російського істеблішменту як держава із сумнівною історичною легітимністю, що «природно має належати до пріоритетних інтересів Кремля».

Ситуація, яка має місце сьогодні у російсько-українських відносинах, повинна застерегти український політикум та суспільство від можливості повторити помилки столітньої давнини. Крах Російської імперії засвідчив ліквідацію політичного інституту монархічної системи правління. На іï уламках з'явилися незалежні державні утворення. Класична імперія відійшла в історію, а імперські тенденції збереглися в ідеології й теорії російської великодержавності. Критичне переосмислення історичного досвіду відносин між УСРР та РСФРР 1920-х років має наукове і прикладне значення. Тому метою автора $є$ дослідження відносин між РСФРР і УСРР у 1919-1929 рр., встановлення факту їх міждержавного статусу, обставин і політичної мотивації унітаризму у взаєминах.

Маємо констатувати, що період 1919-1929 рр. став переломними у російсько-українських відносинах. Річ у тім, що з установленням у січні 1919 р. влади Тимчасового робітничо-селянського уряду України розпочалося формування організаційно-політичних основ і принципів унітаризму, який трансформувався впродовж наступних років. Цей період у російсько-українських відносинах завершився у 1929 р. Це був сталінський «рік Великого перелому», що означив початок системної «соціалістичної реконструкції», яку ототожнюють із більшовицькою модернізацією. На цей рік припадає початок соціально-економічної реконструкції народного господарства, поява класичної командно-адміністративної системи в СРСР, посилення централізаторських тенденцій, утрата договірних зобов'язань між республіками, елементів формального суверенітету. [1, с. 5]. Україна, за визначенням М. Волобуєва, стала колонією у «народногосподарському комплексі» СРСР [2, с. 48].

Аналіз історіографії з проблеми дослідження взаємовідносини РСФРР та УСРР у 1919-1929 рр. дав змогу констатувати, що проблему в історіографії висвітлювали широко і суперечливо - від «вічної дружби» до «вічного антагонізму» (Б. Бабій [3], В. Галкін [4], Д. Златопольський [5], С. Якубовська [6], М. Шаповал [7], О. Медушевський [8], Т. Коржихіна [9], В. Чеботарьова [10]). Вагомий внесок у дослідження відносин між радянськими Україною та Росією належить сучасним українським історикам (С. Кульчицький [11], Г. Єфіменко [12], М. Дмитрієнко [13], В. Марочко [14], В. Сергійчук [15]).

Вивчення праць істориків, дослідження опублікованих та архівних документів доводить, що більшовицька доктрина радянського державного будівництва визначалася принципом політичної доцільності і трансформувалася відповідно до завдань, які ставила перед собою РКП(б). У вказаному хронологічному періоді російсько-українських відносин за допомогою суспільно-політичного та економічного критеріїв у російській радянській політиці щодо УСРР нам удалося виокремити шість етапів. Перший припадає на листопад 1917 р. - середину 1918 р. і характеризується початком формування цих відносин після розпаду Російської імперії. На цьому етапі відбувається розгортання Української національнодемократичної революції і прихід більшовиків до влади в Росії.

Другий етап припадає на кінець 1918 р. - середину 1919 р. Для нього характерним є спад національно-демократичної революції і розрізненість українських національних сил та агресія російських більшовицьких військ. На третьому етапі (1 червня 1919 р. - 28 грудня 1920 р.) було започатковано процес створення союзної держави під зверхністю РСФРР. Період із 28 грудня 1920 р. по липень 1923 р. відносимо до четвертого етапу. Тут відносини між республіками набули характеру військово-господарського, дипломатичного і політичного союзу. За п’ятого етапу (друга половина 1923-1925 рр.) відбулося конституційне оформлення СРСР, зміцнення однопартійної політичної системи, обмеження декларованого суверенітету союзних республік. Шостий етап (1926-1929 рр.) оцінюємо як етап стандартизації, боротьби з ухилами, уніфікації управління «народногосподарським комплексом», нівелювання суб'єктності УСРР.

Фактично політично-програмні формулювання більшовицьких лозунгів «права націй на самовизначення», «національно-культурна автономія» виявилися декларативними, теоретичною поступкою «націоналам». За період 1920-х років більшовики доктринально упорядкували російсько-імперський політично-економічний та адміністративно-територіальний комплекс, сприймали його як єдине ціле. За цей час було здійснено радянізацію (совєтизацію) територіального простору України. Особливо це відбувалося в умовах змагальності владних структур УНР та російсько-більшовицької адміністрації, що мало наслідком структурно-теоретичну і функціонально-інституційну окупацію, ідеологічну експансію й силову інкорпорацію українських земель. У результаті більшовицька агітаційно-пропагандистська 
ідеологічна теза «триумфальное шествие советской власти» перетворилася на зайвий історичний доказ тактично-стратегічного втілення російської ідеології, зорієнтованої на поглинання територій під лозунгом епохи перших московських царів, - «собирание земель».

Формально у період 1919-1923рр. радянська Україна мала державно-правовий статус суверенної республіки. Ї̈̈ структурно-функціональні ознаки - власний Наркомат закордонних справ, участь у міжнародних конвенціях, двосторонніх угодах, повпредства тощо - вказували на суб'єктність у міжнародних відносинах. Однак українська внутрішня і зовнішня політика обмежувалися монопартійною політично системою та відповідною номенклатурою, унітарним принципом монополії зовнішньої торгівлі. Інституційно-функціональний паралелізм у діях урядів УСРР та РСФРР 1920-х років (дублювання Конституції РСФРР 1918 р., ключових декретів) був не випадковістю. Він став закономірністю внаслідок поетапної унітарності політично-адміністративної системи влади в УСРР.

Воєнно-політичний союз радянських республік, оформлений декретом від 1 червня 1919 р., формально створював «міждержавне» об'єднання воєнних, політичних і економічних ресурсів самостійних національних республік (РСФРР, України, Білорусії, Латвії, Литви і Естонії). Однак він став практично першим кроком на шляху формування унітарної держави тоталітарного типу. Фактично набула чинності ідеологема «старшого брата»: захист радянських республік із боку Росії, поширення законодавства РСФРР, радянсько-російської грошової системи та так званого «загальнофедеративного бюджету». Водночас відбувалася «зачистка» тих українських політичних партій, які пропонували альтернативний проєкт функціонування радянської держави в Україні.

Об'єднавчий рух республік на шляху до унітарної держави виявився успішним ідеологічним і політичним проєктом більшовиків. Декрет всеросійського ЦВК «Про об’єднання радянських республік: Росії, України, Латвії, Литви, Білорусії для боротьби зі світовим імперіалізмом» від 1 червня 1919 р. означав реалізацію більшовицької доктрини централізації системи управління, створення єдиної союзної держави під егідою РСФРР [16, ст. 264]. Воєнно-політичний союз уніфікував стратегічні галузі промисловості, транспорт, фінанси, керівництво якими зосереджувалося в руках московських «єдиних колегій». До складу ВЦВК і РНК РСФРР запросили представників радянських республік [1, с. 14].

У партійному і державному керівництві РСФРР прибічники «єдиної і неподільної Росії» скористалися «воєнно-політичним союзом», а загрозу інтервенції й контрреволюції використали для мотивації входження незалежних радянських республік до складу Радянської Росії на правах автономій. Доказом прискорення фактичного об'єднання республік є Постанова Всеукрревкому від 27 січня 1920 р. «Про об'єднання діяльності УСРР і РСФРР» [17, с. 2]. Не чекаючи остаточного оформлення взаємовідносин між республіками, нею скасовувалися усі нормативні акти уряду УСРР, що стосувалися діяльності ключових господарських і військових органів, та замінювалися відповідними нормативними актами уряду РСФРР. Декрети і постанови РНК РСФРР набирали чинності на всій території України з моменту їх опублікування і підлягали негайному виконанню. Відбувся своєрідний «аншлюс», який декларував суверенність України, а насправді позбавив ії самостійності в управлінні стратегічними галузями економіки, навіть у їі сільському господарстві, запровадивши систему розверстки і продрозверстки. Російськими більшовиками було продемонстровано віртуозну майстерність ідеологічної маніпуляції. Обіцянками скільки завгодно суверенітету насправді системно і послідовно здійснювалося насаджування власного проєкту формування величезної за територією, але унітарної по своїй суті держави.

Договір між РСФРР і УСРР від 28 грудня 1920 р. уже встановлював два ключові принципи правових взаємовідносин між РСФРР і УСРР: незалежність і суверенність кожної зі сторін, що беруть участь у цьому договорі; спільність політичних і соціальних завдань та єдність інтересів у питаннях оборони й господарського будівництва. За цим договором РСФРР і УСРР, будучи суб'єктами міжнародних відносин, вступили у військово-господарський союз. Насправді ж відбулося банальне підпорядкування українських наркоматів фінансів, зовнішньої торгівлі, праці, військових і морських справ, транспорту, пошт і телеграфу, а також Вищої ради народного господарства російськими. Усі вони мали своїх представників в урядах республік. Однак управління цими наркоматами покладалося на Всеросійський ЦВК та Всеросійський з’їзд Рад робітничих, селянських і червоноармійських депутатів [1, с. 15].

В історіографії міжреспубліканських відносин союзний договір 28 грудня 1920 р. постає етапним, проміжним. [14, с. 49]. Історично він став першим законодавчим актом двосторонніх міждержавних відносин, про що зазначено у преамбулі самого договору. Номінально обидві республіки були незалежними одна від одної, адже так звані федеративні зв'язки (наявність загальнофедеративного бюджету, спільні колегії наркоматів) мали умовно-інституційний статус. Класичної федерації, навіть попри заяви і політичні прагнення окремих більшовицьких лідерів, УСРР та РСФРР не створили. Договірна федерація формувалася на підставі договору між ії суб'єктами у складі єдиної держави з конституційно виписаними повноваженнями, тому відносини між ними до січня 1924 р. мали виразні елементи 
міждержавних (повпредства за кордоном, інститут обопільних представництв, двосторонні угоди, регламентовані торгово-економічні зв'язки, уряди).

Спочатку російських більшовиків влаштовувала декларативна федералізація, яка унеможливила фрагментацію самої ідеї великодержавності й територіальної цілісності колишніх національних окраїн. Політичні проєкти унітарності (федералізація, конфедерація, національно-культурна автономія), які постійно обговорювали на Політбюро ЦК РКП(б), пленумах, засвідчили іï незворотність, тактичний задум прихильників «єдиноцентризму» на шляху до створення унітарної держави тоталітарного типу. Партійна система з ії монополізмом розвивалася саме за подібним сценарієм: гасло «диктатура пролетаріату» означало диктатуру партії, а остання породжувала диктатуру вождя.

До конституційного оформлення СРСР та інституційного статусу унітарної держави (1923-1924рр.) відносини між РСФРР та УСРР зберігали формальні ознаки міждержавних. Їх подальша політична перспектива уніфікувалася союзним законодавством, нівелюванням виразної суб'єктності, придушенням будь-яких форм «республіканського сепаратизму», навіть «ухильництвом» у царині національно-культурного розвитку. Дискусії про «теорію двох культур», фабрикація національних ухилів («хвильовизм», «шумськизм», «волобуєвщина»), які розгорнулися в Україні у другій половині 1920-х років, на нашу думку, удар на випередження прояву реального сепаратизму. У галузі державного будівництва виникла проблема повноважень суб'єктів СРСР і національно-автономних республік РСФРР. На нараді 1926 р. у М. Калініна постала гостра дилема: або «підтягнути» суб'єкти федерації радянської Росії до статусу УСРР (республіканського), або ж «опустити» іï до рівня автономії РСФРР [1, с. 15].

Окрім того, проголошуючи право націй на самовизначення, більшовики формально обходили й проблеми кордонів, дотримуючись ідеї неподільності території колишньої імперії. Уперше питання про територіальне розмежування між радянськими республіками постало на міжвідомчій нараді при економічно-правовому відділі НКВС РСФРР 25 лютого 1919 р. Досягнуті угоди стали основою затвердженого 25 лютого 1919 р. «Договору про кордони з РСФРР» [12, с. 136]. Згідно із цим договором, чотири північні повіти Чернігівської губернії передали до новоутвореної Гомельської губернії РСФРР. Для відбудови економіки та якнайшвидшого вирішення паливно-енергетичної проблеми на початку 1920 р. вирішили створити Донецьку губернію. До утвореної ще на початку 1919 р. Донецької губернії у складі Бахмутського і Слов'яносербського (Луганського) повітів долучили частину Області Війська Донського та низку сільськогосподарських районів. Оскільки більшість населення новоствореної губернії за своїм етнічним складом була українською, її територія була передана до складу УСРР [15, с. 386]. Економічна доцільність виявилася домінантною, незважаючи на україномовну більшість районів Луганщини, російськомовних на Дону, але ці території вирішили передати у підпорядкування Раднаркому УСРР.

Під час міждержавного розмежування за основу бралися межі територіально-адміністративних одиниць царської Росії, які не узгоджувалися з національними принципами. Територіальне розмежування між радянськими республіками, здійснене за вказівкою Кремля у 1920-х роках, сьогодні довело, що утворені тоді нові кордони значною мірою не відповідали етнічним. Поза межами УСРР залишилися райони компактного проживання українців на Гомельщині, Брянщині, Курщині, Воронежчині, а також на Дону та Північному Кавказі. Фактично визнавалися державними адміністративні кордони українських земель, що входили до Російської імперії у складі дев'яти губерній $[1$, с. 16].

Визначення території та кордонів України у межах декларованої федерації було питанням внутрішнім і не обов'язковим для термінового розв'язання. Однак міжреспубліканські двосторонні угоди зобов' язували створення адміністративно-територіальних комісій у РСФРР і УСРР. У січні 1920 р. при Президії ЦВК РСФРР було створено Адміністративну комісію ВЦВК і Держплану РСФРР, а $з$ квітня 1920 р. при Народному комісаріаті внутрішніх справ УСРР почала діяти Адміністративно-територіальна комісія [1, с. 16].

3 утворенням СРСР питання про кордони знову набуло актуальності. Національний склад населення за територіального розмежування попередніх років ураховувався лише на губернському рівні. Проєкт з урегулювання зовнішніх кордонів УСРР і РСФРР, що висувався Україною, включав три основних моменти: етнографічний, економічний та географічний. Мотивами слугували необхідність вирівнювання існуючої лінії українсько-російського кордону і більш зручної організації адміністративного управління, а також однорідність національного складу прилеглих частин території РСФРР до УСРР і економічного тяжіння.

Установленню чітких меж між УСРР і сусідніми республіками сприяла Центральна адміністративнотериторіальна комісія, створена у листопаді 1922 р. при Всеукраїнському Центральному Виконавчому Комітеті. Дискусійним стало питання про неспівпадіння етнографічних кордонів України з кордонами дев'яти губерній УСРР, заселених переважно українцями. Намагання радянської влади продемонструвати міжнародній спільноті справедливе вирішення національного питання, масові клопотання 
населення, постанови пленумів повітових виконавчих комітетів про включення їх до складу УСРР, коренізація у поєднанні з адміністративно-територіальною реформою поставили на порядок денний питання про корегування міжреспубліканських кордонів. Політика коренізації відіграла роль каталізатора у питанні приєднання до УСРР Кубані, Чорноморщини, Південної Курщини, Південної Воронежчини, Західної Донщини з переважаючим українським населенням, яке зазнавало русифікації [1, с. 16].

Для практичного врегулювання кордону 11 квітня 1924 р. Постановою Президії ЦВК СРСР була створена спеціальна Союзна комісія з урегулювання кордонів між РСФРР, УСРР і БСРР на чолі з головою ЦВК Білоруської СРР О. Черв'яковим. У результаті проведеної роботи поза межами УСРР залишилося понад 2 млн українців, що компактно мешкали на землях Курської, Воронезької губерній та Північно-Кавказького краю РСФРР. Постановою ЦВК СРСР від 16 жовтня 1925 р. «Про врегулювання кордонів УСРР з РСФРР і БСРР» за підписом Голови ЦВК СРСР М. Калініна до складу Північно-Кавказького краю РСФРР відійшло вісім районів Шахтинської округи 3 м. Шахти і шість районів Таганрозької округи з м. Таганрог [13, с. 393]. На цій території знаходилося майно всеукраїнського значення: шахти, заводи, радгоспи, дослідна станція Наркомзему тощо.

Ознаки економічного характеру (сільське господарство, промисловість тощо) підтверджували доцільність установлення державного кордону між УСРР і РСФРР по межі розселення українців. У результаті адміністративно-територіальних перетворень 1920-х років, непоступливості РСФРР Україна втратила великі території на Сході. Цілеспрямована політика керівництва СРСР 1920-х років призвела до того, що великі за площею, населені переважно українцями землі залишилися поза межами політичних кордонів України [1, с. 16].

Отже, започаткований у роки російської революції принцип унітаризму за формою «єдиноцентризму» поступово і системно реалізовувався впродовж 1920-х років. Усе, що приховувалося під титулом «союзний», функціонально означало «загальноросійський». Партійно-радянську номенклатуру в Україні призначала Москва, а загальносоюзні наркомати перебрали на себе функції колишніх «федеральних» об’єднаних наркоматів, позбавили самодіяльності республіканську управлінську вертикаль.

Геополітична стратегія радянської влади грунтувалася на прагненні звести до мінімуму територію Української СРР, максимально уніфікувати чисельність її населення, яке етнічно належало або тяжіло до України. Залежність УСРР від московського центру не дала їй змоги встановити свої кордони згідно з розселенням українців. Існувала колосальна різниця між теоретичним проголошенням національної політики та їі практичним утіленням.

\section{Література:}

1. Сокирська В.В. Відносини між РСФРР і УСРР (1919-1929 рр.): політико-економічний та адміністративно-територіальний дискурс : автореф. дис. ... д-ра іст. наук : 07.00.02. Тернопіль, 2018. 44 с.

2. Волобуєв М. До проблеми української економіки. Більшовик Украӥни. 1928. № 2. С. 46-73.

3. Бабій Б. Союз РСР і роль України в його утворенні. Київ, 1972. 255 с.

4. Галкин В. Возникновение и развитие социалистических наций в СССР. Москва : Госполитиздат, 1952.112 с.

5. Златопольский Д. СССР - федеративное государство. Москва : МГУ, 1967. 334 с.

6. Якубовская С.И. Строительство Союзного Советского социалистического государства в 1922-1925 гг. Москва : Академия наук СССР, 1960. 402 c.

7. Шаповал М. Большевизм і Україна. Прага : Вільна спілка, 1926. 62 с.

8. Медушевский А.Н. Перестройка и причины крушения СССР с позиций аналитической истории. Российская история. 2011. № 6. С. 3-30.

9. Коржихина Т.П. Советское государство и его учреждения: ноябрь 1917 г. - декабрь 1991 г. Москва : РГГУ, 1994. $418 \mathrm{c}$.

10. Чеботарева В.Г. Национальная политика Российской Федерации. 1925-1938 гг. Москва : Московский дом национальностей, 2008. 832 c.

11. Кульчицький С. Утворення СРСР: нові погляди. Україна: культурна спадщина, нащіональна свідомість, державність. 15/2006-2007. С. 684-699.

12. Єфіменко Г. Визначення кордону між УСРР та РСФРР (1917-1920). Проблеми історії Украӥни: факти, судження, пошуки. 2011. Вип. 20. С. 135-176.

13. Дмитрієнко М.Д. Зміни в адміністративно-територіальному устрої України в 1919-1920рр. Украӥнський історичний журнал. 2004. № 1. С. 43-52.

14. Марочко В. Модернізація українського суспільства перехідного періоду 1920-1930-х років: історико-теоретичний аспект. Проблеми історії України: факти, судження, пошуки. 2003. № 8. С. 43-51.

15. Сергійчук В. Етнічні межі і державний кордон України. Київ : ПП Сергійчук М.I., 2008. 560 с.

16. Собрание узаконений и распоряжений рабочего и крестьянского правительства РСФСР. 1919. Ст. 264.

17. Известия Всеукрревкома. 30 января 1920 г. Ч. 35. 